Bangladesh J. Bot. 49(4): 1045-1051, 2020 (December)

\title{
ANTIFUNGAL ACTIVITY AND GC-MS ANALYSIS OF N-BUTANOL EXTRACT OF QUINOA (CHENOPODIUM QUINOA WILLD.) LEAVES
}

\author{
IQRA HaIder KhaN* AND Arshad JaVaId \\ Institute of Agricultural Sciences, University of the Punjab, Lahore, Pakistan
}

Keywords: Antifungal constituents, Quinoa, Macrophomina phaseolina, Natural fungicides

\begin{abstract}
Dry leaves of quinoa (Chenopodium quinoa Willd.) were extracted in methanol and its $n$-butanol fraction was separated. Solvent was evaporated and antifungal bioassays were carried out against Macrophomina phaseolina using different concentrations (1.562, 3.125, 6.25, 12.50, 25, 50, 100, $200 \mathrm{mg} / \mathrm{ml}$ ) of the extract in malt extract broth. The entire set of concentrations significantly controlled the fungal growth. The lowermost concentration of the extract $(1.562 \mathrm{mg} / \mathrm{ml})$ reduced $M$. phaseolina biomass by $62 \%$ over control while all other concentrations completely controlled fungal growth. GC-MS analysis showed that there were 20 compounds in this fraction. Stigmasta-7,16-dien-3-ol was the predominant compound with peak area of $15.14 \%$ followed by 1-butanol, 3-methyl- (11.87\%), $\beta$-sitosterol $(9.93 \%), \gamma$-sitosterol $(8.84 \%)$, butane, 2-[1-methylethyl) thio]- $(6.51 \%)$, cyclohexane, 1,1-dimethoxy- $(6.27 \%)$, stigmasterol $(5.98 \%)$ and stigmastanol (4.57\%). The compounds such as 1-butanol, 3-methyl-; $\gamma$-sitosterol and stigmasterol present in $n$-butanol fraction of methanolic leaf extract of quinoa are highly and likely to be responsible for antifungal activity against $M$. phaseolina.
\end{abstract}

\section{Introduction}

The soil-borne fungal pathogen Macrophomina phaseolina causes diseases in more than 500 host plant species in tropical, subtropical, semi-arid and arid areas of the globe (Rayatpanah et al. 2012). In Pakistan, it has 67 economically important host plant species including mungbean, mashbean, soybean, sunflower, sorghum, maize, linseed, chickpea and alfalfa (Pawlowski et al. 2015, Javaid et al. 2017). The observed disease symptoms are visible in lateral and main roots of crop plants with distal portions black in color. As the disease progresses, it provokes the root system destruction along with chlorosis, growth losses, withering, and ultimately death of the host plants (Khan et al. 2019).

Fungicides are considered as one of the most important methods against the fungal attacks for protecting the crop plants. However, most of the fungicides are toxic in nature and pollute the environment, so a possible alternative way out to solve the problem is the use of readily available natural compounds from plants (Mitrani et al. 2018). This strategy is useful for protecting plants against the resistance development in pathogenic fungal populations and to provide a cheap alternate to the poor rural farmers (Ncama et al. 2019). Plants are the most important source of chemical compounds. There is growing evidence that these compounds when applied on other plants, they can protect the plant from the pathogens. In the search of environmentally safer, selective and durable natural pesticides, structural identification of these compounds is required (Hossain et al. 2019). Several scientists have provided evidences that many of the plant species possess antifungal properties (Sana et al. 2017, Javaid et al. 2018, Shoaib et al. 2018, Sajeena et al. 2019).

Members of family Chenopodiaceae are known to possess antifungal properties against $M$. phaseolina and other fungal pathogens (Javaid and Amin 2009, Ali et al. 2017). Quinoa (Chenopodium quinoa) belongs to Chenopodiaceae family and is known as a pseudo-cereal crop

*Author for correspondence: <iqrahaider_khan@yahoo.com>. 
of South America recently introduce in Europe, North America, Asia and Africa. It is becoming a high value crop because of its remarkable tolerance to heat, drought and salinity (Hinojosa et al. 2019, Manaa et al. 2019). It is a natural food source for humans because of its high quality and nutrition values (Hernandez-Ledesma 2019). In the recent years, trials have been conducted for its cultivation in Pakistan. Hopefully, in near future a significant biomass of quinoa will be available after its harvest in Pakistan. Among other uses of this biomass, being a member of an antifungal family Chenopodiaceae, it may be used as soil amendment to control plant pathogens. Therefore, this study was carried out to explore antifungal activity of $n$-butanol fraction of methanolic leaf extract of quinoa against M. phaseolina.

\section{Materials and Methods}

Methanolic extract of quinoa was prepared by exhaustively extracting coarsely powdered shade dried leaves $(2 \mathrm{~kg}$ ) with methanol (6 litre) at room temperature for 14 days. After coarse filtration by muslin cloth, the extract was filtered using filter papers and was concentrated by recovering the solvents under reduced pressure using a rotary evaporator at $45^{\circ} \mathrm{C}$ that yielded 178 $\mathrm{g}$ of gummy biomass. Then the resulting crude extract was suspended in $200 \mathrm{ml}$ of distilled water, and the resultant was successively subjected to fractionation process in a separating funnel using different organic solvents beginning with $n$-hexane $(4 \times 500 \mathrm{ml})$. The remaining aqueous phase was partitioned with chloroform $(500 \mathrm{ml})$, ethyl acetate $(500 \mathrm{ml})$, and $n$-butanol $(500 \mathrm{ml})$. Among these solvents, $n$-butanol was evaporated to obtain $n$-butanol extract (Akhtar and Javaid 2018). The in vitro biological activity of $n$-butanol fraction was assessed against $M$. phaseolina. Out of the $n$-butanol extract, $1.2 \mathrm{~g}$ was added to $1 \mathrm{ml}$ of dimethyl sulphoxide (DMSO) followed by the addition of $5 \mathrm{ml}$ of malt extract to prepare $200 \mathrm{mg} / \mathrm{ml}$ concentration stock solution and divided into two aliquots. One aliquot was used for further serial dilution to make the lower concentrations viz., $100,50,25,12.5,6.25,3.125,1.562 \mathrm{mg} / \mathrm{ml}$ and the other one was used to evaluate extract bio-efficacy. Control treatment was prepared by adding $5 \mathrm{ml}$ of ME broth and $1 \mathrm{ml}$ of DMSO in pre-sterilized glass test tubes and serially double diluted. Inoculum of $M$. phaseolina was prepared from 8-day-old culture in autoclaved distilled water. The assay was performed by adding $50 \mu 1$ aliquots of the inoculum in each test tube and left to stand for 7 days at $28^{\circ} \mathrm{C}$. Fungal biomass was filtered and weighed after seven days of incubation (Shafique et al. 2016). Three replicates of each treatment were run simultaneously in a completely randomized design. All the data were analyzed by ANOVA followed by LSD test $(\mathrm{p} \leq 0.05)$ using computer software Statistix 8.1.

\section{Results and Discussion}

$n$-Butanol faction was found highly antifungal against the fungal pathogen. The lowermost concentration $(1.562 \mathrm{mg} / \mathrm{ml})$ significantly suppressed fungal biomass by $62 \%$ over control. All other concentrations completely controlled (100\%) fungal growth (Fig. 1). Earlier, Stuardo and Martin (2008) reported that quinoa extract suppressed mycelial growth of Botrytis cinerea. Furthermore, antifungal activity of the extract was increased by treating them with alkali. Likewise, Glen-Karolczyk (2016) found aqueous extracts of different parts of quinoa highly antifungal against mycelial growth and sporulation of various phytopathogenic fungi, namely Sclerotinia sclerotiorum, Rhizoctonia solani, Botrytis cinerea and Fusarium poae. Antifungal activity of quinoa may be attributed to presence of various phenolics, flavonoids and saponins (Stuardo and Martin 2008, Miranda et al. 2014).

Twenty compounds were present in $n$-butanol fraction as revealed by GC-MS analysis (Figs. 2 and 3, Table 1). The most abundant compound was stigmasta-7,16-dien-3-ol followed by 1butanol, 3-methyl- with 15.14 and $11.87 \%$ peak areas, respectively. The 2 nd most abundant 
compound 1-butanol, 3-methyl- was also a major constituent of the mixture of volatile organic compounds (VOCs) of Saccharomyces cerevisiae with antimicrobial activity against many phytopathogens. A dose $\geq 1 \mu \mathrm{l} / \mathrm{ml}$ of this compound completely inhibited in vitro growth of Colletotrichum acutatum and C. gloeosporioides, the cause of anthracnose disease of guava (Rezende et al. 2015). Likewise, the VOCs of endophytic Diaporthe strains EC-4 were effective

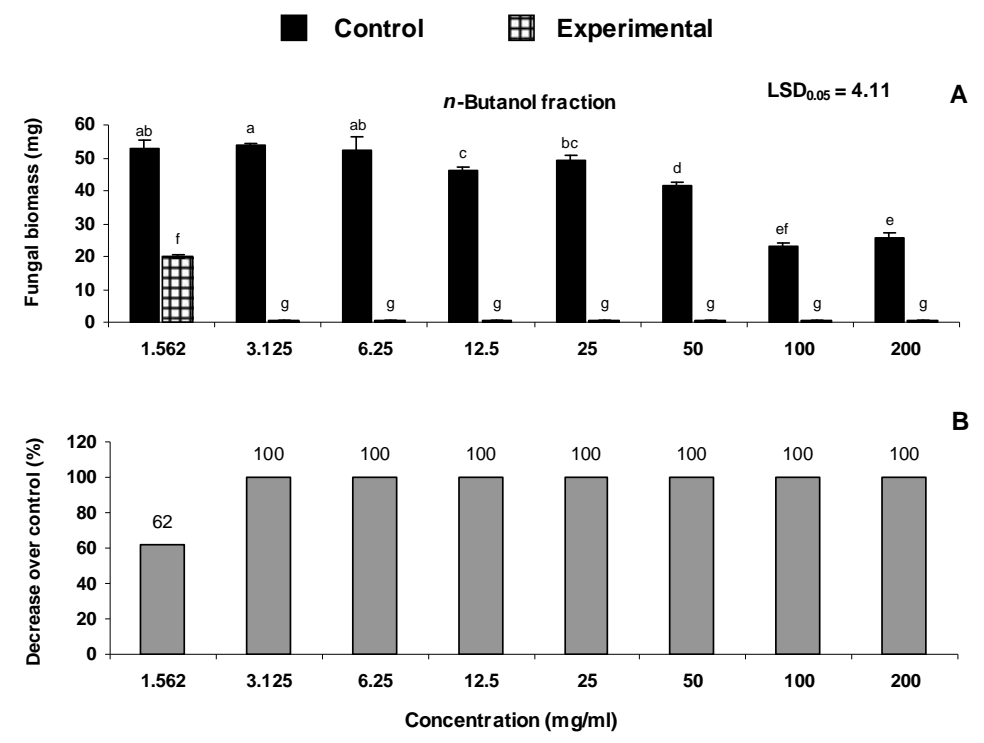

Fig. 1. Effect of different concentrations of $n$-butanol and aqueous fractions of methanolic leaf extract of Chenopodium quinoa on biomass of Macrophomina phaseolina. Vertical bars show standard errors of means of four replicates. Values with different letters at their top show significant difference $(\mathrm{p} \leq 0.05)$ as determined by LSD test.

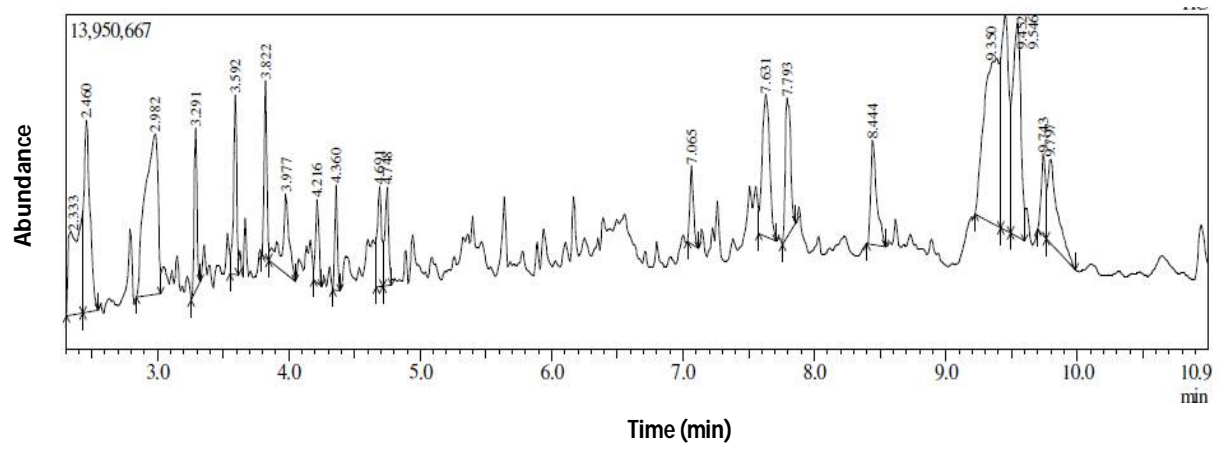

Fig. 2. GC-MS chromatogram of $n$-butanol fraction of methanolic leaf extract of Chenopodium quinoa.

against oomycete Phytophthora cinnamomi possibly because of presence of 1-butanol, 3-methyl(Yan et al. 2018). Other compounds present in high abundance in the present study were $\beta$-sitosterol (9.93\%) and $\gamma$-sitosterol (8.84\%). Among these, $\gamma$-sitosterol was previously identified in Saccostrea glomerata and was found to possess fungicidal properties against various fungal species (Karthikeyan et al. 2014). Likewise, $\beta$-sitosterol exhibited antifungal activity against Candida albicans (Moshi et al. 2004). 


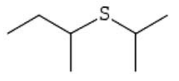

1. Butane, 2-[1methylethyl) thio]-

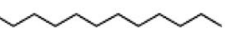

4. Dodecane

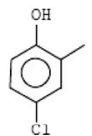

7. Phenol, 4-chloro-2 methyl-

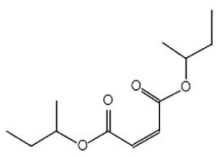

10. 2-Butenedioic $\operatorname{acod}(\mathrm{Z})-$, bis(1-methylpropyl) ester

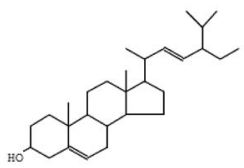

13. Stigmasterol

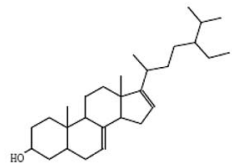

16. Stigmasta-7,16-dien-3-ol

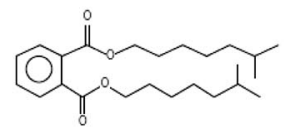

19. 1,2-Benzenedicarboxylic acid, diisooctyl ester

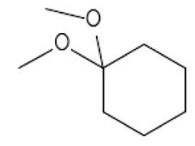

2. Cyclohexane, 1,1dimethoxy-

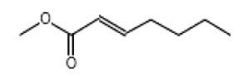

5. 2-Heptenoic acid, methyl ester

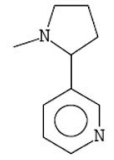

8. Pyridine, 3-(1-methyl2-pyrrolidinyl), (S)-

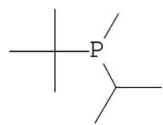

11. Phosphine, (1,1-dimethylethyl) methyl(1-methylethyl)-

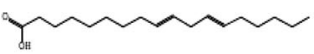

14. 9,12-Octadecadienoic acid $(\mathrm{Z}, \mathrm{Z})-$

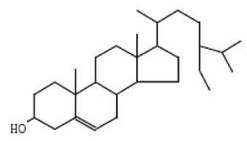

17. $\gamma$-Sitosterol

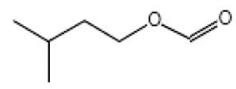

3. 1-Butanol, 3-methyl-

6. Tridecane

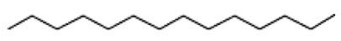

9. Tetradecane

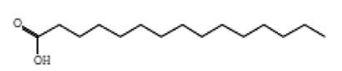

12. Pentadecanoic acid

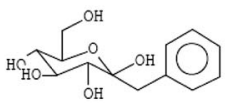

15. Benzyl beta.-d-glucoside

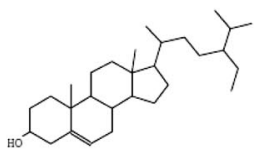

18. $\beta$-Sitosterol

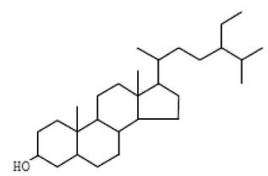

20. Stigmastanol

Fig. 3. Structures of compounds identified in $n$-butanol fraction of methanolic leaf extract of Chenopodium quinoa through GC-MS.

Moderately abundant compounds included butane, 2-[1-methylethyl) thio]- (6.51\%), cyclohexane, 1,1-dimethoxy- (6.27\%), and stigmasterol (5.98\%). Among these, earlier stigmasterol isolated from bark of Neocarya macrophylla showed antifungal activity against Candida krusei and C. albicans with MIC values of $12.5-50 \mu \mathrm{g} / \mathrm{ml}$ as compared to MIC value of $5 \mu \mathrm{g} / \mathrm{ml}$ of standard antifungal agent fluconazole (Yusuf et al. 2018). Compounds, namely stigmastanol 
(4.57\%), 9,12-octadecadienoic acid (Z,Z)- (4.42\%), benzyl.beta.-d-glucoside (3.56\%), 2-heptenoic acid, methyl ester (3.24\%), phenol, 4-chloro- 2 methyl- (3.23\%), tridecane (2.74\%), dodecane (2.63\%), 2-butenedioic acid (Z)-, bis(1-methylpropyl)ester (2.26\%), phosphine, (1,1-dimethylethyl) methyl(1-methylethyl)- (2.13\%) and 1,2-benzenedicarboxylic acid, diisooctyl ester

Table 1. List of compounds in $n$-butanol fraction of methanolic leaf extract of Chenopodium quinoa identified by GC-MS analysis.

\begin{tabular}{cllccc}
\hline $\begin{array}{c}\text { Sl. } \\
\text { No. }\end{array}$ & Names of compounds & $\begin{array}{l}\text { Molecular } \\
\text { formula }\end{array}$ & $\begin{array}{c}\text { Molecular } \\
\text { weight }\end{array}$ & $\begin{array}{c}\text { Retention } \\
\text { time (min) }\end{array}$ & $\begin{array}{c}\text { Peak area } \\
(\%)\end{array}$ \\
\hline 1 & Butane, 2-[1-methylethyl) thio]- & $\mathrm{C}_{7} \mathrm{H}_{16} \mathrm{~S}$ & 132 & 2.333 & 6.51 \\
2 & Cyclohexane, 1,1-dimethoxy- & $\mathrm{C}_{8} \mathrm{H}_{16} \mathrm{O}_{2}$ & 144 & 2.460 & 6.27 \\
3 & 1-butanol, 3-methyl- & $\mathrm{C}_{6} \mathrm{H}_{12} \mathrm{O}_{2}$ & 116 & 2.982 & 11.87 \\
4 & Dodecane & $\mathrm{C}_{12} \mathrm{H}_{26}$ & 170 & 3.291 & 2.63 \\
5 & 2-heptenoic acid, methyl ester & $\mathrm{C}_{8} \mathrm{H}_{14} \mathrm{O}_{2}$ & 142 & 3.592 & 3.24 \\
6 & Tridecane & $\mathrm{C}_{13} \mathrm{H}_{28}$ & 184 & 3.822 & 2.74 \\
7 & Phenol, 4-chloro-2 methyl- & $\mathrm{C}_{7} \mathrm{H}_{7} \mathrm{ClO}$ & 142 & 3.977 & 3.23 \\
8 & Pyridine, 3-(1-methyl-2-pyrrolidinyl), (S)- & $\mathrm{C}_{10} \mathrm{H}_{14} \mathrm{~N}_{2}$ & 162 & 4.216 & 1.54 \\
9 & Tetradecane & $\mathrm{C}_{14} \mathrm{H}_{30}$ & 198 & 4.360 & 1.52 \\
10 & 2-butenedioic acod (Z)-, bis(1-methylpropyl) ester & $\mathrm{C}_{12} \mathrm{H}_{20} \mathrm{O}_{4}$ & 228 & 4.691 & 2.26 \\
11 & Phosphine, (1,1-dimethylethyl) methyl(1-methylethyl)- & $\mathrm{C}_{8} \mathrm{H}_{19} \mathrm{P}$ & 146 & 4.748 & 2.13 \\
12 & Pentadecanoic acid & $\mathrm{C}_{15} \mathrm{H}_{30} \mathrm{O}_{2}$ & 242 & 7.065 & 1.57 \\
13 & Stigmasterol & $\mathrm{C}_{29} \mathrm{H}_{48} \mathrm{O}$ & 412 & 7.631 & 5.98 \\
14 & 9,12-Octadecadienoic acid (Z,Z)- & $\mathrm{C}_{18} \mathrm{H}_{32} \mathrm{O}_{2}$ & 280 & 7.793 & 4.42 \\
15 & Benzyl beta-d-glucoside & $\mathrm{C}_{13} \mathrm{H}_{18} \mathrm{O}_{6}$ & 270 & 8.444 & 3.56 \\
16 & Stigmasta-7,16-dien-3-ol & $\mathrm{C}_{29} \mathrm{H}_{48} \mathrm{O}$ & 412 & 9.350 & 15.14 \\
17 & $\gamma$-sitosterol & $\mathrm{C}_{29} \mathrm{H}_{50} \mathrm{O}$ & 414 & 9.452 & 8.84 \\
18 & B-sitosterol & $\mathrm{C}_{29} \mathrm{H}_{50} \mathrm{O}$ & 414 & 9.546 & 9.93 \\
19 & 1,2-Benzenedicarboxylic acid, diisooctyl ester & $\mathrm{C}_{24} \mathrm{H}_{38} \mathrm{O}_{4}$ & 390 & 9.743 & 2.08 \\
20 & Stigmastanol & $\mathrm{C}_{29} \mathrm{H}_{52} \mathrm{O}$ & 416 & 9.767 & 4.57 \\
\hline
\end{tabular}

(2.08\%) were less abundant. Three compounds, namely pentadecanoic acid (1.57\%), pyridine, 3-(1methyl-2-pyrrolidinyl), (S)- (1.54\%), and tetradecane (1.52\%) were least abundant as shown in Table 1 and Fig. 3. Among the less and least abundant compounds, tridecane, tetradecane and 1,2benzenedicarboxylic acid, diisooctyl ester are known to possess antifungal activity against a variety of fungal species (Ozdemir et al. 2004, Shafiqur-Rehman and Anwar 2006, Begum et al. 2016).

It is concluded that $3.125 \mathrm{mg} / \mathrm{ml}$ concentration of $n$-butanol fraction of methanolic leaf extract of Chenopodium quinoa can completely control the growth of M. phaseolina. 1-Butanol, 3methyl-; $\gamma$-sitosterol and stigmasterol were possibly be the major constituents of this fraction responsible for antifungal activity.

\section{References}

Akhtar R and Javaid A 2018. Biological management of basal rot of onion by Trichoderma harzianum and Withania somnifera. Planta Daninha. 36: e017170507.

Ali A, Javaid A and Shoaib A 2017. GC-MS analysis and antifungal activity of methanolic root extract of Chenopodium album against Sclerotium rolfsii. Planta Daninha. 35: e017164713. 
Begum IF, Mohankumar R, Jeevan M and Ramani K 2016. GC-MS analysis of bio-active molecules derived from Paracoccus pantotrophus FMR19 and the antimicrobial activity against bacterial pathogens and MDROs. Indian J. Microbiol. 56: 426-432.

Glen-Karolczyk K, Witkowicz R and Elżbieta B 2016. In vitro study on the use of quinoa (Chenopodium quinoa Willd.) extracts to limit the development of phytopathogenic fungi. J. Agric. Eng. Res. 61: 132138.

Hernandez-Ledesma B 2019. Quinoa (Chenopodium quinoa Willd.) as source of bioactive compounds: A review. Biol. Comp. Health Dis. 2: 27-47.

Hinojosa L, Matanguihan JB and Murphy KM 2019. Effect of high temperature on pollen morphology, plant growth and seed yield in quinoa (Chenopodium quinoa Willd.). J. Agron. Crop Sci. 205: 33-45.

Hossain MA, Biva IJ, Kidd SE, Whittle JD, Griesser HJ and Coad BR 2019. Antifungal activity in compounds from the Australian desert plant Eremophila alternifolia with potency against Cryptococcus spp. Antibiotics 8: 34-40.

Javaid A and Amin M 2009. Antifungal activity of methanol and $n$-hexane extracts of three Chenopodium species against Macrophomina phaseolina. Nat. Prod. Res. 23: 1120-1127.

Javaid A, Afzal L and Shoaib A 2017. Biological control of charcoal rot of mungbean by Trichoderma harzianum and shoot dry biomass of Sisymbrium irio. Planta Daninha. 35: e017165756.

Javaid A, Shahzad GR, Akhtar N and Ahmed D 2018. Alternaria leaf spot disease of broccoli in Pakistan and management of the pathogen by leaf extract of Syzygium cumini. Pak. J. Bot. 50: 1607-1614.

Karthikeyan SC, Velmurugan S, Donio MBS, Michaelbabu M and Citarasu T 2014. Studies on the antimicrobial potential and structural characterization of fatty acids extracted from Sydney rock oyster Saccostrea glomerata. Ann. Clin. Microbiol. Antimicrob. 13: 332.

Khan MM, Firdous H, Tahir Z, Zahid K, Haider MA, Qadus A, Sultan A, Hussan M and Mushtaq MS 2019. Response of commercial and candidate lines of soybean (Glycine max L.) against root rot disease and its chemicals management. Discov. Agric. 5: 29-40.

Manaa A, Goussi R, Derbali W, Cantamessa S, Abdelly C and Barbato R 2019. Salinity tolerance of quinoa (Chenopodium quinoa Willd.) as assessed by chloroplast ultrastructure and photosynthetic performance. Environ. Exp. Bot. 162: 103-114.

Miranda M, Delatorre-Herrera J, Vega-Gálvez A, Jorqueral E, Quispe-Fuentes I and Martínez EA 2014. Antimicrobial potential and phytochemical content of six diverse sources of quinoa seeds (Chenopodium quinoa Willd.). Agric. Sci. 5: 1015-1024.

Mitrani E, Perdum E, Iordache OG and Dumitrescu I 2018. Advantages and disadvantages of pesticide analysis methods used in agricultural samples. Sci. Papers Ser. B Hort. 62: 709-714.

Moshi M, Joseph C, Innocent E and Nkunya M 2004. In vitro antibacterial and antifungal activities of extracts and compounds from Uvaria scheffleri. Pharm. Biol. 42: 269-273.

Ncama K, Mditshwa A, Tesfay SZ, Mbili NC and Magwaza LS 2019. Topical procedures adopted in testing and application of plant-based extracts as bio-fungicides in controlling postharvest decay of fresh produce. Crop Prot. 115: 142-151.

Ozdemir G, Karabay NU, Dalay MC and Pazarbasi B 2004. Antibacterial activity of volatile component and various extracts of Spirulina platensis. J. Phytother. Res, 18:744-757.

Pawlowski ML, Hill CB and Hartman GL 2015. Resistance to charcoal rot identified in ancestral soybean germplasm. Crop Sci. Soc. Am. 55: 1230-1235.

Rayatpanah S, Nanagulyan SG and Ala SV 2012. Pathogenic and genetic diversity among Iranian isolates of Macrophomina phaseolina. Chil. J. Agric. Res. 72: 40-44.

Rezende DC, Fialho MB, Brand MC and Pascholati SF 2015. Antimicrobial activity of volatile organic compounds and their effect on lipid peroxidation and electrolyte loss in Colletotrichum gloeosporioides and Colletotrichum acutatum mycelia. Afr. J. Microbiol. Res. 9: 1527-1535.

Sajeena A, John J, Sudha B, Meera AV and Karthika SR 2019. Significance of botanicals for the management of plant diseases. In: Plant Health Under Biotic Stress. Springer, Singapore. pp. 231-243. 
Sana N, Javaid A and Shoaib A 2017. Antifungal activity of methanolic leaf extracts of allelopathic trees against Sclerotium rolfsii. Bangladesh J. Bot. 46: 987-993.

Shafique S, Shafique S and Yousuf A 2016. Bioefficacy of extract of Ageratum conyzoides against Drechslera australiensis and Drechslera holmii. Pak. J. Phytopathol. 27: 193-200.

Shafiqur-Rehmen M and Anwar MN 2006. Fungitoxic and cytotoxic activity of a novel compound 1,2benzenedicarboxylic acid, diisooctyl ester of Plumbago zeylanica Linn. Asian J. Microbiol. Biotechnol. Environ. Sci. 8: 661-664.

Shoaib A, Munir M, Javaid A, Awan AZ and Rafiq M 2018. Anti-mycotic potential of Trichoderma spp. and leaf biomass of Azadirachta indica against the charcoal rot pathogen Macrophomina phaseolina (Tassi) Goid in cowpea. Egypt. J. Biol. Pest Control. 28: 26.

Stuardo M and Martin RS 2008. Antifungal properties of quinoa (Chenopodium quinoa Willd.) alkali treated saponins against Botrytis cinerea. Ind. Crops Prod. 27: 296-302.

Yan DH, Song X, Li H, Luo T, Dou G and Strobel G 2018. Antifungal activities of volatile secondary metabolites of four Diaporthe strains isolated from Catharanthus roseus. J. Fungi (Basel). 4: 65.

Yusuf AJ, Abdullahi MI, Aleku GA, Ibrahim IAA, Alebiosu IO and Yahaya M 2018. Antimicrobial activity of stigmasterol from the stem bark of Neocarya macrophylla. J. Med. Plants Econ. Dev. 2: a38. 